\title{
SISTEM INFORMASI DAN POTENSI MANFAAT BIG DATA UNTUK PENDIDIKAN
}

\author{
Doni Heryana $^{1}$, Linda Setiawati ${ }^{2}$, Budi Suhendar ${ }^{3}$ \\ ${ }^{1}$ Program Pasca Sarjana Teknologi Pendidikan, Institut Pendidikan Indonesia, \\ e-mail: doni.heryana@gmail.com \\ ${ }^{2}$ Program Studi Perpustakaan dan Informasi Universitas Pendidikan Indonesia \\ Email : lindasetiawati@upi.edu \\ ${ }^{3}$ SDN Bojong Kecamatan Pameungpeuk Garut \\ Email : budisuhendar@gmail.com
}

\begin{abstract}
ABSTRAK
Informasi dapat didefinisikan sebagai hasil pengolahan data dalam bentuk yang lebih bagi penerima untuk menggambarkan peristiwa nyata yang digunakan untuk membuat keputusan. Sumber informasi adalah data. Data adalah bentuk jamak dari bentuk tunggal atau data-idem. Data adalah kenyataan yang menggambarkan peristiwa nyata dan persatuan. Sistem informasi dapat didefinisikan sebagai sistem dalam organisasi yang merupakan kombinasi dari orang, fasilitas, teknologi, media, prosedur, dan kontrol yang bertujuan untuk memperoleh jalur komunikasi penting, proses, jenis transaksi, memberikan sinyal kepada manajemen dan mereka yang orang lain untuk peristiwa internal dan eksternal yang penting dan memberikan dasar untuk informasi untuk keputusan yang cerdas. Teknologi Informasi dan Komunikasi (TIK) merupakan topik penting yang berkembang dalam berbagai kebijakan publik, tak terkecuali dalam bidang pendidikan. Integrasi TIK dalam kehidupan sehari-hari mengubah hubungan kita dengan informasi dan pengetahuan. Big Data menjamin pemrosesan solusi data dengan yang baru dan varian yang ada ada untuk memberikan manfaat nyata bagi bisnis Prospek data besar pada saat yang sama membangkitkan pandangan optimis tentang masa depan yang kaya informasi dan di sisi lain tentang kekhawatiran tentang dampak negatif teknologi yang berdampak buruk pada pembangunan karakter generasi muda saat ini.
\end{abstract}

Kata kunci : Sistem Informasi, Big Data

\section{ABSTRACT}

Information can be defined as the result of data processing in a form that is more for the recipient to describe a real event that is used to make a decision. The source of information is data. Data is the plural of the singular or data-idem form. Data is a reality that describes a real event and unity.Information systems can be defined as a system within an organization that is a combination of people, facilities, technology, media, procedures, and controls aimed at obtaining important communication lines, processes, certain types of transactions, giving signals to management and those who others to important internal and external events and provide a basis for information for smart decisions. Information and Communication Technology (ICT) is an important topic that develops in various public policies, not least in the field of education. The integration of ICT in everyday life changes our relationship with information and knowledge. Big Data guarantees the processing of data solutions with new and existing variants to provide tangible benefits for business. The prospect of big data at the same time evokes an optimistic view of the information rich future and on the other hand about concerns about the negative impact of technology that has a negative impact on character building for today's young generation.

Keyword: Information System; Big Data 


\section{A. PENDAHULUAN}

Ledakan informasi adalah tanda peluang dan tantangan yang akan dihadapi manusia di masa depan. Perkembangan volume informasi yang dipicu, ditransfer, dan diterima akan terus berlanjut dan semakin menggelembung. Bersamaan dengan itu, informasi juga meningkat. Pada saat itu manusia akan hidup dalam masyarakat baru, yaitu masyarakat informasi. Informasi membutuhkan saluran untuk bergerak. Saluran adalah saluran komunikasi. Teknologi siap memenuhi kebutuhan ini, dengan perkembangan teknologi komunikasi yang memungkinkan komunikasi antara pengirim dan penerima yang berjauhan dalam waktu singkat. Akibatnya, batas ruang dan waktu menjadi semakin kabur. Teknologi Informasi dan Komunikasi (TIK) merupakan topik penting yang berkembang dalam berbagai kebijakan publik, tak terkecuali dalam bidang pendidikan. Integrasi TIK dalam kehidupan sehari-hari mengubah hubungan kita dengan informasi dan pengetahuan.

Sekarang kita telah memasuki era big data, era di mana ada pertumbuhan eksponensial dalam jumlah data sebagai akibat dari pesatnya perkembangan teknologi. Big Data adalah istilah umum untuk setiap kumpulan set data dalam jumlah yang begitu besar dan kompleks yang membuatnya sulit untuk ditangani atau diproses jika hanya menggunakan manajemen basis data biasa atau aplikasi pemrosesan data tradisional, Big Data menjamin pemrosesan solusi data dengan yang baru dan varian yang ada ada untuk memberikan manfaat nyata bagi bisnis.

Pendidikan adalah salah satu sektor yang menjadi perhatian khusus bagi pemerintah dari waktu ke waktu. Pada setiap pergantian kekuasaan, sektor ini tidak kebal dari perubahan kebijakan. Beberapa kali di Indonesia pendidikan telah mengalami perubahan kurikulum, bahkan kurikulum terbaru 2013 dibatalkan untuk beberapa sekolah karena dianggap tidak pantas. Sudah saatnya bagi pemerintah dan sekolah untuk mencoba berkolaborasi dengan teknologi dalam hal ini. Salah satu teknologi yang dapat membantu adalah analisis data besar.

\section{B. KAJIAN LITERATUR}

Berbicara tentang informasi, itu tidak dapat dipisahkan dari data. Oleh karena itu, sebelum memahami konsep informasi dalam hal ini akan dibahas secara singkat tentang data tersebut. Menurut Susanto (2002) data adalah fakta atau apa saja yang dapat digunakan sebagai input dalam menghasilkan informasi. Data dapat berupa bahan untuk diskusi, pengambilan keputusan, perhitungan, atau pengukuran. Saat ini data tidak harus dalam bentuk kumpulan huruf dalam bentuk kata atau kalimat, tetapi bisa juga dalam bentuk suara, gambar diam dan bergerak, baik dalam bentuk dua atau tiga dimensi. Bahkan sekarang mulai banyak dikembangkan data virtual / virtual yang merupakan hasil rekayasa komputer. Jelas menurut Siagian (2002) data adalah bahan "mentah". Sebagai bahan baku, data adalah input yang, setelah diproses, berubah menjadi keluaran yang disebut informasi.

Menurut Susanto (2002) informasi adalah hasil dari pengolahan data, tetapi tidak semua hasil dari pengolahan tersebut dapat berupa informasi. Hasil pengolahan data yang tidak memberi arti atau makna dan tidak bermanfaat bagi seseorang bukanlah informasi untuk orang tersebut. Dari uraian informasi ada tiga hal penting yang harus diperhatikan, antara lain:

1. informasi adalah hasil dari pengolahan data

2. Memberi makna

3. Berguna atau bermanfaat.

Selain memahami informasi ini Mc. Leod (Susanto, 2002) mengemukakan bahwa informasi yang berkualitas harus memiliki karakteristik sebagai berikut:.

1. Akurat, artinya informasi mencerminkan situasi sebenarnya. 
Pengujian masalah ini biasanya dilakukan melalui pengujian yang dilakukan oleh dua orang atau lebih yang berbeda dan jika hasil tes ini menghasilkan hasil yang sama, maka data tersebut dianggap akurat.

2. Tepat waktu berarti bahwa informasi harus tersedia atau tersedia ketika informasi itu diperlukan, bukan besok atau tidak beberapa jam.

3. Relevan artinya informasi yang diberikan harus sesuai kebutuhan. Jika informasi ini diperlukan untuk suatu organisasi, informasi tersebut harus sesuai dengan kebutuhan informasi di berbagai tingkatan dan bagian dalam organisasi.

4. Lengkap berarti informasi harus diberikan secara lengkap.

Dengan memahami bahwa informasi adalah hasil dari pengolahan data melahirkan pikiran lain. Apa artinya apakah pemrosesan data hanya terjadi sekali? Bagaimana jika setelah diproses, diproses lagi? Apakah informasi yang diproses dan diproses ulang tetap menjadi informasi atau menjadi data? Gambar berikut, dapat memperjelas bagaimana hubungan antara data dan informasi.

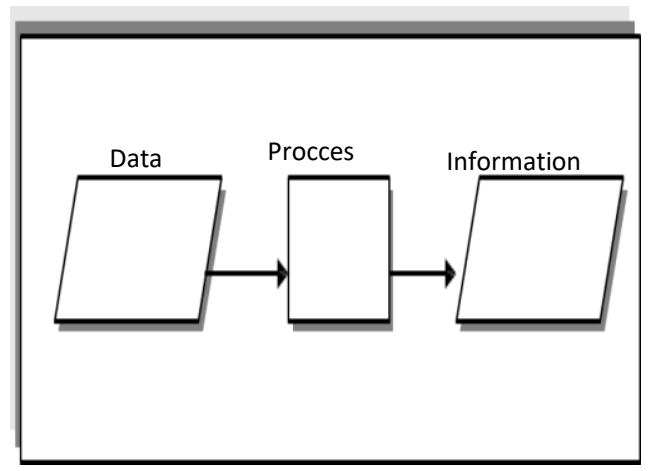

Gambar 1.1 Model dasar sistem informasi

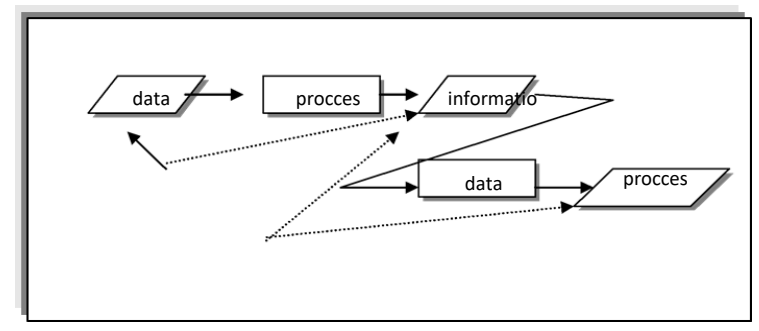

Gambar 1.2 Informasi pemrosesan ulang
Berdasarkan Gambar 1.2 di atas, dapat disimpulkan bahwa pada waktu-waktu tertentu data dan informasi berbeda. Tetapi di lain waktu sesuatu yang telah menjadi informasi mungkin menjadi data dalam pemrosesan selanjutnya, atau sesuatu yang menjadi informasi untuk orang A, bagi orang B mungkin data yang harus diproses lebih lanjut untuk menghasilkan informasi. Selain memahami informasi, menurut Nasution (2001) informasi adalah sesuatu yang lebih sementara daripada pengetahuan. Informasi memiliki nilai bagi seseorang, seperti informasi harga saham, berita utama, saldo bank, atau informasi di mana membeli sepatu yang bagus, semua itu bersifat sementara (sesaat) dan tidak berarti abstrak. Informasi dapat berkontribusi pada pengetahuan dalam arti digunakan untuk mendukung atau menolak teori.

Berbicara mengenai informasi menurut Koswara (1998) tidak pernah ada informasi yang "netral". Suatu informasi selalu dibuat berkaitan dengan konteks pola pikir tertentu untuk melayani kebutuhan, baik kebutuhan nasional, organisasi, dan pribadi atau pribadi. Informasi tidak dapat dikatakan baik atau buruk. Penilaian semacam itu hanya dilakukan oleh pengguna informasi yang sangat bergantung pada pengetahuan dan perspektif masing-masing. Untuk alasan ini, kita harus memiliki pengetahuan yang memadai tentang berbagai sumber informasi. Memahami keberagaman informasi akan membantu kami untuk mengakomodasi, menganalisis, dan menyebarkan informasi lebih lanjut. Jika itu tidak terlihat oleh kita, bukan tidak mungkin untuk menyebabkan kebingungan dan penganiayaan informasi yang mencapai kita.

Pada April 2014 Google Inc. mencatat sekitar 100 miliar permintaan pencarian per bulan. Menurut Sugiarsono (2015) angkaangka ini menunjukkan bahwa pergerakan data sangat besar hingga saat ini dan akan terus tumbuh. Ini menunjukkan bahwa pengejaran pengetahuan yang sesungguhnya telah menjadi hobi manusia, bahkan sejak pengetahuan pertama kali 
dicatat. Selain data raksasa dari proyek genom manusia dan data luar angkasa NASA, menurut Cukier (2010) setelah tragedi 11 September 2001, Departemen Pertahanan AS meluncurkan sebuah program yang disebut Total Information Awareness, yang mengumpulkan banyak data sebanyak mungkin tentang segala sesuatu termasuk di dalamnya e-mail, panggilan telepon, pencarian web, transaksi belanja, catatan bank, data rekam medis, riwayat perjalanan dan banyak lagi. Sejak 1996 Kahle Brewster, seorang pengusaha internet, telah mencatat semua konten itu di web sebagai bisnis nirlaba, yang ia sebut sebagai Internet Archive. Sejak itu data yang disimpan bahkan telah diperluas untuk mencakup perangkat lunak, film, rekaman audio, dan pemindaian buku.Gary King (2016), profesor di Universitas Harvard, menyatakan bahwa big data tidak selalu tentang data. Bukan data yang menciptakan masalah, tetapi analisis dan untuk itu kita membutuhkan mesin baru dan teknologi yang lebih canggih untuk mengatasinya. Dengan demikian dapat dikatakan bahwa data selalu tersedia dan dapat dikumpulkan atau dikumpulkan, sehingga itu bukan masalah besar. Tetapi fokusnya adalah pada analisis big data yang tersedia dan teknologi yang dibutuhkan untuk mengelolanya untuk menghasilkan informasi yang berguna bagi manusia. Informasi ini diperlukan untuk membuat keputusan atau kebijakan penting yang pada gilirannya akan mempengaruhi kehidupan manusia nantinya. Dengan melakukan itu data telah menjadi informasi. Informasi itu akan ditransformasikan menjadi pengetahuan yang dapat diterapkan dalam kehidupan manusia sehari-hari.

\section{METODE PENELITIAN}

Penelitian ini menggunakan metode penelitian deskriptif kuantitatif dan kajian pustaka. Penelitian deskriptif kuantitatif dilakukan untuk mengetahui gambaran apa adanya secara angka terhadap bahan/kajian yang sedang diteliti. Kajian pustaka yang dilakukan dalam penelitian ini berupaya menginformasikan kepada pembaca hasilhasil penelitian lain yang berkaitan erat dengan penelitian yang dilakukan. Penelitian deskriptif juga tidak menguji hipotesis atau membuat prediksi. Penelitian ini diartikan melukiskan variable satu demi satu secara berurutan.

Penelitian deskriptif digunakan untuk (1) mengumpulkan informasi aktual secara rinci yang menjelaskan gejala yang ada, (2) menidentifikasi masalah atau memeriksa kondisi dan praktek-praktek yang berlaku, (3) membuat perbandingan atau evaluasi, (4) menentukan apa yang dilakukan orang lain dalam menghadapi masalah yang sama (Yogaswara, dkk: 2018). Sedangkan kajian pustaka dimaksudkan sebagai mana dimaksud oleh Anderson adalah untuk untuk meringkas, menganalisis, dan menafsirkan konsep dan teori yang berkaitan dengan sebuah proyek penelitian.

\section{HASIL DAN PEMBAHASAN}

Teknologi Informasi dan Komunikasi (TIK) sebagai bagian dari ilmu pengetahuan dan teknologi (IPTEK) secara umum adalah semua yang teknologi berhubungan dengan pengambilan, pengumpulan (akuisisi), pengolahan, penyimpanan, penyebaran, dan penyajian informasi (Kementerian Negara Riset dan Teknologi, 2006: 6). Tercakup dalam definisi tersebut adalah semua perangkat keras, perangkat lunak, kandungan isi, dan infrastruktur komputer maupun (tele)komunikasi. Istilah TIK atau ICT (Information and Communication Technology), atau yang di kalangan negara Asia berbahasa Inggris disebut sebagai Infocom, muncul setelah berpadunya teknologi komputer (baik perangkat keras maupun perangkat lunaknya) dan teknologi komunikasi sebagai sarana penyebaran informasi pada paruh kedua abad ke-20. Perpaduan kedua teknologi tersebut berkembang sangat pesat, jauh melampaui bidang-bidang teknologi lainnya. Bahkan sampai awal abad ke-21 ini, dipercaya bahwa bidang TIK masih akan terus pesat berkembang dan belum terlihat titik jenuhnya sampai beberapa dekade 
mendatang. Pada tingkat global, perkembangan TIK telah mempengaruhi seluruh bidang kehidupan umat manusia. Intrusi TIK ke dalam bidang-bidang teknologi lain telah sedemikian jauh sehingga tidak ada satupun peralatan hasil inovasi teknologi yang tidak memanfaatkan perangkat TIK.

Teknologi Informasi dan Komunikasi (TIK) merupakan topik penting yang berkembang dalam berbagai kebijakan publik, tak terkecuali dalam bidang pendidikan. Integrasi TIK dalam kehidupan sehari-hari mengubah hubungan kita dengan informasi dan pengetahuan. Peluang yang ditawarkan oleh penggunaan TIK dalam pendidikan begitu banyak jumlahnya, sehingga dapat mengarah pada pengalaman belajar yang lebih baik dan lebih menarik. Efek ini tidak hanya terbatas pada ruang kelas, tetapi juga transformasi model pendidikan, contohnya seperti model jarak jauh ke model e-learning atau \& yang menawarkan pilihan baru dalam penyampaian, serta peluang baru dalam layanan pelatihan guru dan dukungan lain. Kapasitas TIK untuk membangun jaringan tanpa batas merupakan kemungkinan pembelajaran inovatif yang setara di seluruh wilayah dan negara. Kemampuan siswa untuk memanfaatkan TIK sudah menjadi kebutuhan baru untuk sistem pendidikan yang efektif.

Hubungan Big Data dengan Bidang Pendidikan Prospek data besar pada saat yang sama membangkitkan pandangan optimis tentang masa depan yang kaya informasi dan di sisi lain tentang kekhawatiran tentang dampak negatif teknologi yang berdampak buruk pada pembangunan karakter generasi muda saat ini. Dampak perkembangan teknologi tidak terhindarkan sehingga yang dibutuhkan saat ini adalah bagaimana mendidik generasi muda saat ini untuk menjadi pembelajar online yang baik sehingga mereka dapat dengan bijak menggunakan dan memanfaatkan teknologi.
Karena era ini menjanjikan guru dan siswa era baru pembelajaran yang dipersonalisasi, penilaian formatif yang responsif dan pembelajaran kolaboratif. Belajar tidak lagi hanya terikat dengan ruang dan waktu, pembelajaran dapat dirancang untuk diakses kapan saja dan di mana saja dengan memanfaatkan media teknologi.

Contoh keberadaan BIG DATA yang dikelola dan disimpan dan kemudian digunakan dalam dunia pendidikan adalah DAPODIK, Data Pokok Pendidikan atau Dapodik adalah sistem pendataan skala nasional yang terpadu, dan merupakan sumber data utama pendidikan nasional, yang merupakan bagian dari Program perancanaan pendidikan nasional dalam mewujudkan insan Indonesia yang Cerdas dan Kompetitif. Karena tanpa perencanaan pendidikan yang matang, maka seluruh program yang terbentuk dari perencanaan tersebut akan jauh dari tujuan yang diharapkan.

Untuk melaksanakan perencanaan pendidikan, maupun untuk melaksanaan program-program pendidikan secara tepat sasaran, dibutuhkan data yang cepat, lengkap, valid, akuntabel dan terus up to date. Dengan ketersediaan data yang cepat, lengkap, valid, akuntabel dan up to date tersebut, maka proses perencanaan, pelaksanaan, pelaporan dan evaluasi kinerja program-program pendidikan nasional dapat dilaksanakan dengan lebih terukur, tepat sasaran, efektif, efisien dan berkelanjutan. Sehubungan dengan hal tersebut, Departemen Pendidikan Nasional telah mengembangkan suatu sistem pendataan skala nasional yang terpadu dan disebut dengan Data Pokok Pendidikan (Dapodik).

Gambar.1 Alur Bog Data dalam Arah Pembangunan

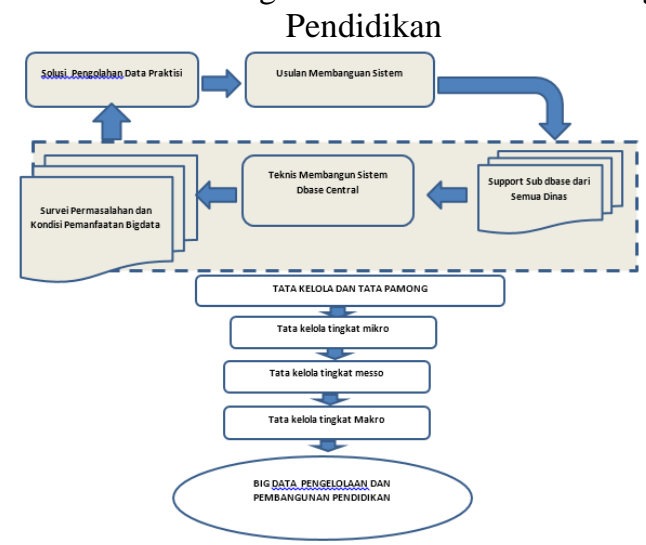


Dengan kemajuan teknologi data besar dan peran penting data besar untuk sistem pendidikan di Indonesia, Salah satunya adalah aplikasi Paques dapat menjadi solusi data besar, Paques adalah aplikasi analitik data besar yang dibuat oleh putra-putra Indonesia. Paques adalah sistem PAQUES Parallel Query yang merupakan teknologi analisis data besar untuk bisnis dan merupakan jawaban terhadap tantangan bisnis big data untuk mengembangkan strategi karena kemudahan operasi untuk kedua profesional bisnis yang tidak memiliki pendidikan atau pengetahuan TI. Keuntungan dari Paques sendiri adalah bahwa Paques memiliki metodologi kerja yang disebut SECAV, yang terdiri dari pencarian, ekstrak, korelasi, agregat, dan visualisasi. Selain itu, Paques dapat melakukan permintaan tunggal yang memberikan berbagai manfaat di berbagai tingkat organisasi yang membutuhkan analisis data besar.

Mungkin semua itu tidak mudah, tetapi bukan tidak mungkin. Tidak ada salahnya menggantungkan masa depan pendidikan kita pada teknologi. pada dasarnya teknologi juga diciptakan untuk memfasilitasi semua urusan manusia. Terutama untuk sektor pendidikan yang memiliki masalah tentang perbedaan dalam kebutuhan pendidikan, dan paques adalah solusi yang baik

\section{Peran Paques}

Paques adalah alat analitik data besar yang dapat memproses dan memproses sejumlah besar data, dari berbagai sumber data yang berbeda dan yang terstruktur atau tidak terstruktur untuk dapat pola yang terjadi sehingga dapat menghasilkan informasi yang berguna dengan cepat. Paques memungkinkan perusahaan untuk tetap fokus dalam membuat keputusan dengan waktu yang lebih singkat dan sumber daya alam dalam upaya mereka untuk mendapatkan informasi yang dibutuhkan, Paques terdiri dari bahasa pencarian yang unik, menggunakan kerangka peta dan mesin pencari sehingga dapat memproses berbagai data.

\section{Metodologi kerja Paques bernama SECAV}

a) Cari, perintah untuk mencari data dalam bentuk file, direktori, indeks, database, dan HDFS. Paques hanya mendukung mesin pencari seperti pencarian layanan internet.

b) Ekstrak, Paques tidak perlu data terstruktur atau tidak terstruktur karena Paques dapat mengekstraksi data "on the fly".

c) Berkorelasi, Paques tidak seperti database relasional antar bidang dalam tabel yang memiliki hubungan satu sama lain. PQL dapat mentolerir dari satu data ke data lainnya.

d) Agregat, Paques memiliki kemampuan untuk mengumpulkan data seperti jumlah, jumlah, jumlah, jumlah, dan fungsi matematika dasar lainnya.

e) Visualisasikan, Paques telah menyediakan modul visualisasi yang cukup lengkap, termasuk untuk keperluan Analisis Jejaring Sosial.

f) Paques dapat digunakan di berbagai industri, terutama di industri yang membutuhkan data dalam jumlah besar yang memiliki banyak variasi dan memprioritaskan hasil yang cepat dan akurat karena Paques dapat menyusun data dengan cepat dan akurat.

\section{E. SIMPULAN DAN REKOMENDASI}

Data dan teknologi adalah sumber daya yang selalu di tengah, tidak pernah memihak, di sisi baik atau di posisi yang berlawanan. Namun, itu semua tergantung pada bagaimana manusia memanfaatkan sumber daya ini. Di era big data, komputer akan menjadi alat yang semakin penting yang digunakan untuk memantau banyak 
hal, membuat lebih banyak keputusan dan bahkan secara otomatis meningkatkan proses mereka sendiri. Sementara itu, manusia akan selalu menghadapi tantangan besar yang sama yang mereka hadapi, yaitu bagaimana memanfaatkan pengetahuan yang mereka miliki menjadi kebijaksanaan yang digunakan untuk kesejahteraan umat manusia. Big data tidak selalu tentang data. Bukan data yang menciptakan masalah, tetapi analisis dan untuk itu kita membutuhkan mesin baru dan teknologi yang lebih canggih untuk mengatasinya. Dengan demikian dapat dikatakan bahwa data selalu tersedia dan dapat dikumpulkan atau dikumpulkan, sehingga itu bukan masalah besar. Tetapi fokusnya adalah pada analisis big data yang tersedia dan teknologi yang dibutuhkan untuk mengelolanya untuk menghasilkan informasi yang berguna bagi manusia. Informasi ini diperlukan untuk membuat keputusan atau kebijakan penting yang pada gilirannya akan mempengaruhi kehidupan manusia nantinya. Dengan melakukan itu data telah menjadi informasi. Informasi itu akan ditransformasikan menjadi pengetahuan yang dapat diterapkan dalam kehidupan manusia sehari-hari.

\section{F. REFERENSI}

Bellinger G., Durval Castro, dan Anthony Mills. (2004). Data, Informasi,

Pengetahuan, dan

Kebijaksanaan diunduh dari http://www.systemsthinking.org/dikw/dikw.htm

Bernstein, JH (2009). Hirarki datainformasi-pengetahuan-

kebijaksanaan dan antitesisnya. Dalam Yakub, EK dan Kwasnik, B. (Eds.). (2009). Prosiding Simposium Amerika Utara tentang Organisasi Pengetahuan Vol. 2, Syracuse, NY, hlm. 68-75.

Bugembe, M. (2013). Menggunakan Big Data dan Analytics untuk Membuka Kedermawanan di Liebowitz, J. (ed.) Big Data dan Analisis Bisnis, Boca Raton, FL: CRC Press.

Cukier K., Ekonom, Data, data di manamana: Laporan khusus tentang pengelolaan informasi, 2010, 27 Februari, diunduh dari https://www.emc.com/collateral/ analyst-reports/ar-the-economistdata- data-everywhere.pdf pada 18 Januari 2017.

Darmawan, Deni, Pendidikan Teknologi Informasi dan Komunikasi, Bandung 2013, PT Rosda.

Koswara, E.1998. Dinamika Informasi dalam Era Globalisasi. Bandung : PT Remaja Rosdakarya.

Kementerian Negara Riset dan Teknologi. 2006. Buku Putih. Penelitian Pengembangan dan Penerapan IPTEK Bidang Teknologi Informasi dan Komunikasi Tahun 2005-2025. Jakarta: Kementerian Negara Riset dan Teknologi.

King, G., 2016, Pendahuluan: Big Data Bukan Tentang Data! dalam Ilmu Sosial Komputasi: Penemuan dan Prediksi, R. Michael Alvarez (Editor). Cambridge: Cambridge University Press.

Majumdar, Arun K. \& John F. Sowa. (2013). Big Data: Terstruktur dan Tidak Terstruktur dalam Liebowitz, J. (ed.) Big Data dan Analisis Bisnis, Boca Raton, FL: CRC Press.

Nasution. 2001. Manajemen Mutu Terpadu (Total Quality Management), Anggota IKPI, Ghalia Indonesia: Jakarta.

Robertson, Terry Dwain. (2013). "Hierarki Data / Informasi / Pengetahuan / Kebijaksanaan Pergi ke Seminari," Kemajuan dalam Studi Informasi dan Agama: Vol. 3 
Pasal 7 tersedia

di http://digitalcommons.kent.edu/asir/vol3

/iss $1 / 7$

Sugiarsono, Joko. (5-18 Maret 2015). SWA sembada Media Bisnis. XXXI (05), 3246.

Susanto, Azhar. 2002. Sistem Informasi Manajemen, Edisi 2. Lingga Jaya Bandung.

Supovitz, J. dan John Weathers, "Lampu Dashboard: Pemantauan Implementasi Strategi Reformasi Instruksional Distrik," Philadelphia: Konsorsium University of Pennsylvania untuk Penelitian Kebijakan dalam Pendidikan, Desember, 2004 dalam DM Barat (2012). Big Data untuk Pendidikan: Penambangan Data, Analisis Data, dan Dasbor Web. Studi Tata Kelola di Brooking diunduh dari http://www.insidepolitics.org/broo kingsreports/education big data. pdf

Turban, E., Ephraim McLean \& James Wetherbe. (2004). Teknologi Informasi untuk Manajemen: Mengubah Organisasi dalam Ekonomi Digital . San Francisco: John Wiley \& Sons, Ltd.

Yayasan Tech

America. (2012). Demystifying

bigdata: Panduan praktis untuk mengubah bisnis

Pemerintah . Diunduh

dari http://www.techamerica.org/Docs/ fileManager.cfm ? $\mathrm{f}=$ techamericabigdatareport final.pdf pada 16 Januari 2017.

Yogaswara, dkk. 2018. Pengelolaan Kampanye Politik pasangan sabdaguna melalui pagelaran wayang golek dalam pemilikada kabupaten bandung periode 2016-2021. Bandung. Jurnal Gunahumas UPI. 